\title{
reviews
}

IND'S Studies in Pre-Vesalian L Anatomy* is a massive work; a stout quarto of more than 300 doublecolumned pages, which has been meticulously researched in libraries and archives in Europe and America. The fruits of Professor Lind's labours of the past 12 years are abundant. We are given 16th century documents-wills, letters, university and municipal records -which previously have never been published. We are given biobibliographies of eight pre-Vesalian anatomists. Finally, Lind provides elaborately annotated translations of six anatomical treatises originally published between 1497 and 1559. The result is a wonderfully full picture of the state of anatomy in the half century before Andreas Vesalius' De humani corporis fabrica (1543) transformed the subject. While Vesalius' genius is actually thrown into relief by comparison with his contemporaries, Lind's study documents the rich and vibrant anatomical tradition which preceded the Fabrica. Vesalius did not emerge from a vacuum.

With two exceptions, all of these pre-Vesalian anatomists were Italian, a fact which underscores the importance of the Italian universities in 16th century medicine. One of the exceptions was Andrés de Laguna (14991560), a peripatetic Spaniard who spent nine years in Italy. De Laguna wrote more than 30 books, including the Anatomica methodus (1535) which Lind has translated, though this is perhaps the least original of the texts which he has chosen. Though de Laguna himself was a figure of considerable fame, his Anatomica methodus was inferior to various similar works which also preceded Vesalius. One of these was Niccolò Massa's Liber introductorius anatomiae (written by 1536 though dated 1559 on the title page), also translated in the present volume. Educated at Padua, Massa (1499-1569) was an active physician who practised in his native city of Venice and who wrote widely on plague and syphilis. Whereas de Laguna returned solely to the ancients for authority, Massa was aware of the tradition of anatomical study in the west,

*Studies in Pre-Vesalian Anatomy: Biography, Translations, Documents. (Memoirs of the American Philosophical Society, vol. 104.) By L. R. Lind. Pp. 344. (American Philosophical Society, 1975.) $\$ 18.00$.

\author{
Sorry, for copyright \\ reasons some images \\ on this page may not \\ be available online
}

\section{Groundwork for a transformation}

that had begun with Mundinus (1275?1326). Mundinus was also revered by Berengario da Carpi (1460-1530), whose Commentary on Mundinus (1521) is summarised in this volume. Lind published an annotated translation of Berengario's more famous Short Introduction to Anatomy (the Isagogae breves of 1522) in 1959.

Berengario was one of a group of several outstanding anatomists who were prominent between the time of Mundinus and Vesalius : a group which included Gabriele Zerbi (1485-1569), Alessandro Achillini (1463-1512) and Alessandro Benedetti (1450?-1512). Lind has translated Achillini's Annotationes anatomicae (1520) and Benedetti's Anatomice (1502). Lind's work is rounded off with translations of Johannes Dryander's famous, short Anatomia capitis humani (1536) and Giovanni Battista Canano's equally familiar Musculorum humani corporis picturata dissectio (1541?). The well known illustrations of these latter two works are also reproduced.

From this summary the richness of Lind's work should be apparent. Lind provides the material necessary to any consideration of the development of anatomy between about 1500 and 1540 . His annotations point back to the sources-classical, Arabic, and contemporary-of these pre-Vesalian anatomists. He notes the philosophical preoccupation of most of these figures, several of whom were equally at home in the world of 16th century Aristotelianism. In fact, part of Vesalius' suc- cess resulted from the single mindedness with which he pursued anatomy; many of his talented contemporaries lost depth because of their eclectic and catholic enthusiasms; the anatomical treatises which Lind has translated generally present only a fraction of those anatomists' total outputs. His translations are lucid without being anachronistic. Where appropriate, he gives modern anatomical equivalents in parentheses, but he never tries to make these texts appear more modern than they really are. The short, introductory biographical studies of his subjects generally contain new material and full assessments of modern secondary literature.

In sum, this fine work tells us a great deal about the anatomical milieu in which Vesalius worked. It helps us see Vesalius' undoubted genius in clearer perspective. Though Professor Lind's bibliographic enthusiasm will appeal only to a handful of specialists, the work as a whole deserves a wide audience. Together with his earlier translations of Berengario and of Vesalius' Epitome, it permits the Latinless reader to appreciate for himself the development of anatomy in the first half of the 16th century. Translation and annotation may not be the most exciting part of scholarship, but they can be most exacting, and Professor Lind possesses the tenacity and erudition of the ideal translator. At $\$ 18.00$ his latest book is an unusual bargain at a time when book bargains are few and far between. 